\title{
EDUKASI DAMPAK DAN PENCEGAHAN SCREEN DEPENDENCY DISORDER (SDD) SELAMA MASA PANDEMI PADA IBU BALITA DI DESA TELAGAWARU LOMBOK BARAT
}

\author{
Catur Esty Pamungkas"), Siti Mardiyah WD'2), Aulia Amini ${ }^{22}$, Desi Rofita ${ }^{3)}$, Baiq Masdariah ${ }^{3)}$, \\ A.A Muhammad Nur Kasman ${ }^{2)}$

\begin{abstract}
1)Program Studi S1 Kebidanan, Universitas Muhammadiyah Mataram, Mataram, NTB, Indonesia 2)Program Studi D3 Kebidanan, Universitas Muhammadiyah Mataram, Mataram, NTB, Indonesia 3)Program Studi Pendidikan Profesi Bidan Program Profesi, Universitas Muhammadiyah Mataram, Mataram, NTB, Indonesia
\end{abstract}

Corresponding author : Catur Esty Pamungkas

E-mail : catur.esty@gmail.com

\section{Diterima 08 April 2021, Disetujui 12 April 2021}

\begin{abstract}
ABSTRAK
Teknologi berperan penting bagi kehidupan manusia. Kemudahan dalam mengoperasikan gadget, baik itu smartphone, tablet, maupun laptop membuat gadget sangat familiar bagi masyarakat, tanpa terkecuali anak-anak. Fitur yang ada didalamnya membuat tertarik anak- anak yang mengakses gadget (Kementrian Kesehatan RI, 2018). Terpapar gadget di usia dini, dapat menyebabkan ketergantungan Screen Dependency Disorder (SDD). Hal ini terjadi karena otak anak belum berkembang secara sempurna, anak-anak belum dapat membedakan mana hal yang benar dan salah, serta hal yang boleh untuk dilakukan dan yang tidak. Sehingga mereka tidak memiliki kemampuan untuk membatasi penggunaan gadget (Kementrian Kesehatan RI, 2018). Solusi permasalahan yang ditawarkan yaitu edukasi dampak dan pencegahan screen dependency disorder (sdd) selama masa pandemi pada ibu balita di desa telagawaru lombok barat. Setelah diberikan edukasi tentang dampak dan pencegahan kecanduan gadget, ibu balita dibekali modul yang dapat dipelajari di rumah dapat mempraktikan kebiasaan untuk tidak memfasilitasi anak bermain gadget. Jumlah responden yang mengikuti kegiatan ini sebanyak 10 balita. Hasil pengabdian didapatkan pengetahuan ibu balita tentang penggunaan gadget $40 \%$ memiliki pengetahuan kurang, setelah dilakukan post test pengetahuan ibu balita meningkat, didapatkan $80 \%$ ibu meningkat yaitu Baik.
\end{abstract}

Kata kunci: screen dependency disorder; balita; pandemi covid19

\begin{abstract}
Technology plays an essential role in human life. The ease of operating gadgets, be it smartphones, tablets, or laptops, makes devices very familiar to the public, including children. The features in it attract children who access gadgets (Kementerian Kesehatan RI, 2018). Exposure to gadgets at an early age can lead to dependence on Screen Dependency Disorder. This is happening because the child's brain is not yet fully developed; the children are unable to distinguish between right and wrong things, as well as what to do and what not. So they cannot limit the use of gadgets (Kementerian Kesehatan RI, 2018). The solution to the problem offered is impact education and prevention of screen dependency disorder during the pandemic period for mothers of children under five in Telagawaru village, West Lombok. After being given education about the effects and prevention of gadget addiction, mothers provided modules that they can learn from at home to practice the habit of not facilitating children to play with gadgets. The number of respondents who participated in this activity was ten toddlers. The results of the dedication, it's found that the mother's knowledge about the use of gadgets was $40 \%$ less knowledgeable, after the post-test the mother's knowledge increased, it's found that $80 \%$ of the mothers had increased, namely Good
\end{abstract}

Keywords: screen dependency disorder; toddlers; the covid pandemic 19

PENDAHULUAN

Bayi dapat tumbuh dan berkembang dengan baik jika kebutuhan dasarnya terpenuhi, yaitu asah, asih dan asuh. Kebutuhan asah adalah kebutuhan akan stimulasi dini. Pemberian stimulasi dini yang sesuai akan memungkinkan terbentuknya etika, kepribadian yang baik, kecerdasan, kemandirian, keterampilan dan produktivitas yang baik (Heath A and Bainbridge N, 2007).

Di era digital sekarang ini, teknologi berperan penting bagi kehidupan manusia. 
Kemudahan dalam mengoperasikan gadget, baik itu smartphone, tablet, maupun laptop membuat gadget sangat familiar bagi masyarakat, tanpa terkecuali anak-anak. Fitur yang ada didalamnya membuat tertarik anakanak yang mengakses gadget (Kementrian Kesehatan RI, 2018). Terpapar gadget di usia dini, dapat menyebabkan ketergantungan Screen Dependency Disorder (SDD). Hal ini terjadi karena otak anak belum berkembang secara sempurna, anak-anak belum dapat membedakan mana hal yang benar dan salah, serta hal yang boleh untuk dilakukan dan yang tidak. Sehingga mereka tidak memiliki kemampuan untuk membatasi penggunaan gadget (Kementrian Kesehatan RI, 2018).

Sasaran dalam kegiatan pengabdian ini yaitu ibu yang memiliki balita usia 1-5 tahun yang bertempat tinggal di Desa Telagawaru Kecamatan Labuapi Kabupaten Lombok Barat, bersedia untuk mengikuti kegiatan pengabdian masyarakat dan tidak dalam keadaan sakit atau menjalani perawatan. Jumlah sasaran sebanyak 20 peserta, namun dalam pelaksanaannya terdapat peraturan daerah yang perlu dipatuhi terkait upaya pencegahan covid19 yaitu menghindari atau mengurangi jumlah kerumunan, dan mengingat ruanagan tempat pelaksanaan. yang tertutup, maka pelaksanaan pengabdian sebanyak 10 peserta dengan tetap menjalankan protokol kesehatan.

Menurut BPS Indonesia, presentase penduduk usia 5 tahun mengakses internet dalam 3 bulan terakhir menurut tujuan penggunaan internet didapatkan sebanyak $87,20 \%$ akses media sosial, $62,13 \%$ hiburan, akses kebutuhan mengerjakan tugas sekolah $25,86 \%$. Nusa tenggara barat memiliki presentase rumah tangga yang akses internet sebanyak $65,25 \%$ masuk dalam kategori menengah dalam penggunaan internet (Luz Yolanda Toro Suarez, 2019).

Dampak yang ditimbulkan dari penggunaan gadget yang tidak aman berdasarkan Hasil Penelitian yang dilakukan oleh (Wulandari and Hermiati, 2019) menunjukan dari 100 responden sebanyak $66 \%$ responden dengan tingkat kecanduan tinggi, $34 \%$ responden dengan tingkat kecanduan rendah. Dan sebanyak 59\% responden dengan suspek gangguan mental dan emosional. Simpulan, sebagian besar anak mengalami kecanduan gadget dan sebagian besar anak beresiko mengalami gangguan emosial jika orang tua tidak melakukan tindakan bijak dalam penggunaan gadget. Didukung oleh hasil penelitian yang dilakukan oleh (Setianingsih, 2018) terdapat $81,1 \%$ anak menggunakan gadget $<2$ jam perhari dan $82,2 \%$ anak normal dan tidak memeiliki resiko GPPH. Sehingga ada hubungan penggunaan gadget dengan resiko gangguan pemusatan perhatian dan hiperaktivitas pada anak usia pra sekolah.

Seorang anak membutuhkan dukungan untuk mencapai pertumbuhan dan perkembangan sesuai usianya, melalui program 1000 Hari Pertama Kehidupan pemantuan tumbuh kembang dimulai sejak dalam kandungan, kecukupan nutrisi dan stimulasi yang mendukung pertumbuhan dan perkembangan sampai 2 tahun pertama kehidupan anak (Kementerian Koordinator Bidang Kesejahteraan Rakyat, 2013). Setiap anak perlu mendapat stimulasi rutin sedini mungkin dan terus menerus pada setiap kesempatan. Stimulasi tumbuh kembang anak dilakukan oleh ibu dan ayah yang merupakan orang terdekat dengan anak, pengganti ibu/pengasuh anak, anggota keluarga lain dan kelompok masyarakat di Lingkungan rumah tangga masing-masing dan dalam kehidupan sehari-hari. Kurangnya stimulasi dapat menyebabkan penyimpangan tumbuh kembang anak bahkan gangguan yang menetap (Depkes., 2016).

Berdasarkan analisis situasi di atas penulis merasa perlu untuk melaksanakan pengabdian tentang dampak dan pencegahan Screen Dependency Disorder (SDD) pada Balita sehingga ibu yang memiliki balita memiliki pengetahuan dan dapat melakukan pencegahan terhadap pencegahan kecanduan gadget pada balita.

\section{METODE}

Metode kegiatan pengabdian masyarakat ini melibatkan kader Desa Telagawaru Kecamatan Labuapi Kabupaten Lombok Barat. Kegiatan pengabdian mengadopsi langkah-langkah action research yang terdiri dari 4 (empat) tahapan, yaitu : perencanaan, tindakan, observasi dan evaluasi, dan refleksi (Yaumi, Muhammad dan Damopolii, 2014). Memberikan edukasi tentang Screen Dependency Disorder (SDD) pada lbu yang memiliki balita di Desa Telagawaru Kecamatan Labuapi Kabupaten Lombok Barat.

Metode yang dilakukan yaitu memberikan edukasi cara pencegahan Screen Dependency Disorder (SDD) pada Balita dengan deteksi dini penyimpangan emosi pada anak sebagai dampak kecanduang gadget menggunakan Kuesioner Masalah Mental Emosional (KMME). Melakukan evaluasi pengetahuan ibu tentang dampak dan cara pencegahan Screen Dependency Disorder (SDD) pada Balita. 


\section{HASIL DAN PEMBAHASAN \\ Perencanaan}

Koordinasi dan pemberian informasi kegiatan pengabdian kepada mitra, dan perangkat desa dilaksanakan hari senin, 22 Maret 2021 bertempat di Kantor Desa Telagawaru. Tim pelaksana diundang untuk mengadakan pertemuan persiapan pelaksanaan dengan melibatkan mahasiswa Kebidanan sebanyak 3 orang. Pada pembekalan ini juga menjelaskan rangkaian kegiatan secara teknis pelaksanaan pengabdian. Didukung dengan penjelasan yang dilakukan (Priyoto, 2014) Seseorang dapat melakukan suatu tindakan sesuai dengan tujuan, jika orang tersebut memahami dengan benar bahwa tindakan yang dilakukan merupakan tindakan yang wajib dikerjakan.

Sosialisasi kegiatan pengabdian pada desa mitra, Sosialisasi dilakukan dalam bentuk koordinasi dengan melibatkan kader posyandu. Kegiatan sosialisasi dilakukan oleh Tim Pengabdian dengan tetap memperhatikan protokol kesehatan dan selalu menggunakan masker dan menjaga jarak. Sosialisasi dilakukan mengingat pentingnya peran aktif kader dalam merekrut peserta dalam keikutsertaan pengabdian berdasarkan kriteria ibu dan balita dalam kondisi sehat, bersedia mengikuti kegiatan hingga akhir dan bertempat tinggal di wilayah Desa Telagawaru Kecamatan Labuapi Kabupaten Lombok Barat.

Persiapan kegiatan pengabdian tanggal, lokasi pengabdian dan alat dan bahan yang dibutuhkan.

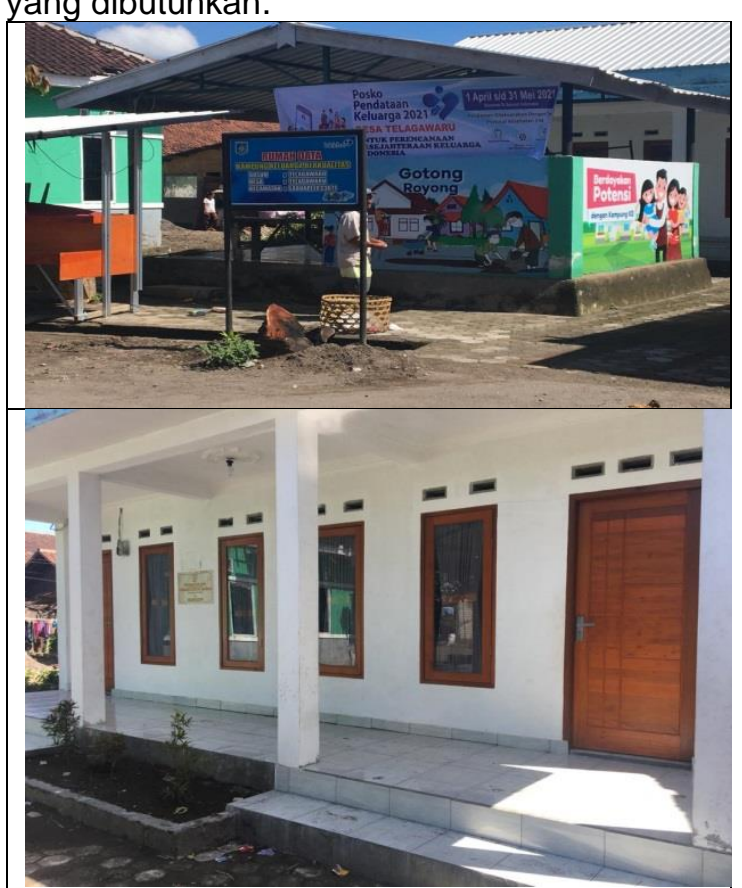

Gambar 2. Lokasi pengabdian masyarakat

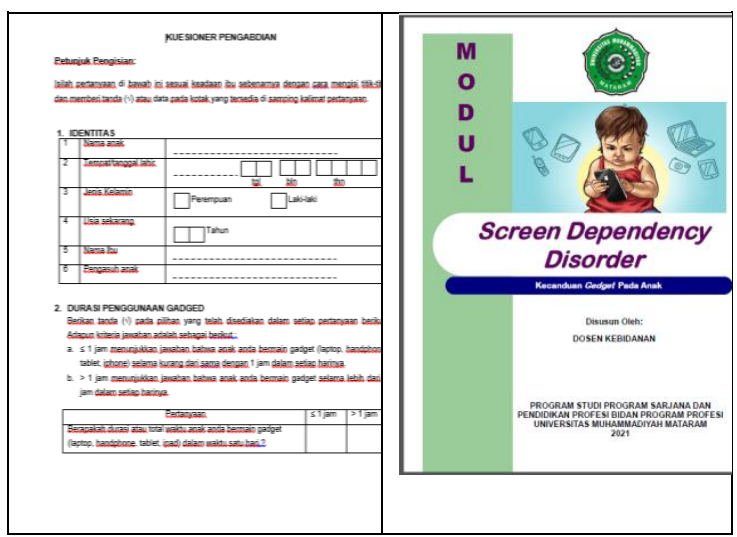

Gambar 2. Kuesioner Pengabdian dan Modul Screen Dependency Disorder.

\section{Tindakan}

Pelaksanaan kegiatan pengabdian tentang edukasi dampak dan pencegahan Screen Dependency Disorder (SDD) pada lbu yang memiliki balita di Desa Telagawaru Kecamatan Labuapi Kabupaten Lombok Barat dilaksanakan pada tanggal Kamis, 25 Maret 2021 bertempat di Sekretariat Kampung (KB) di Desa Telagawaru. Hasil kegiatan yaitu :

a. Distribusi frekuensi berdasarkan karakteristik responden dalam kegiatan pengabdian, yaitu :

Tabel 1. Distribusi frekuensi berdasarkan usia dan jenis kelamin anak

\begin{tabular}{cccc}
\hline \multirow{2}{*}{ Usia } & \multicolumn{2}{c}{ Jenis Kelamin } & \multirow{2}{*}{ Total } \\
\cline { 2 - 3 } & Perempuan & Laki-laki & \\
\hline 1-3 Tahun & 4 & 3 & 7 \\
\hline 4-5 Tahun & 1 & 0 & 1 \\
\hline 6-7 Tahun & 1 & 1 & 2 \\
\hline
\end{tabular}

Didapatkan jumlah responden minoritas yaitu anak perempuan yang memiliki usia 45 tahun yaitu 1 orang, kemudian jumlah responden terbanyak pada anak perempuan usia 1-3 tahun sebanyak 4 orang.

Tabel 2. Distribusi frekuensi berdasarkan Usia dan Durasi Menggunakan Gadget Pada Anak

\begin{tabular}{cc}
\hline \multirow{2}{*}{ Usia } & $\begin{array}{c}\text { Durasi Menggunakan } \\
\text { Gadget }\end{array}$ \\
\cline { 2 - 3 } Total & $\leq 1 \mathrm{jam} \geq 1 \mathrm{jam}$ \\
\hline
\end{tabular}

\begin{tabular}{llll}
\hline 1-3 Tahun & 5 & 2 & 7 \\
\hline 4-5 Tahun & 1 & 0 & 1 \\
\hline 6-7 Tahun & 0 & 2 & 2 \\
\hline \multicolumn{2}{c}{ Didapatkan } & terbanyak & durasi
\end{tabular}

penggunaan gadget $\leq 1$ jam pada usia $1-3$ Tahun sebanyak 5 anak kemudian terkecil untuk kasus durasi menggunakan gadget $\leq$ 1 jamjuga pada usia 4-5 tahun, namu 
terlihat usia terbanyak menggunakan gadget yaitu 1-3 tahun sebanya 7 anak.

b. Distribusi frekuensi berdasarkan dampak penyimpangan Screen Dependency Disorder (SDD).

Tim menilai dampak penyimpangan Screen Dependency Disorder (SDD), responden mengisi kuesioner deteksi dini berupa Kuesioner Masalah Mental Emosional (KMME). Berdasarkan hasil pengkajian didapatkan $40 \%$ anak mengalami masalah mental emosional akibat gadget dan lebih dari 2 pernyataan djawab "Ya", yang artinya anak perlu di Rujuk ke RS yang memiliki fasilitas kesehatan jiwa atau tumbuh kembang anak disertai informasi jumlah dan masalah mental emosional yang ditemukan.

c. Tim memberikan paket modul tentang Screen Dependency Disorder (SDD).

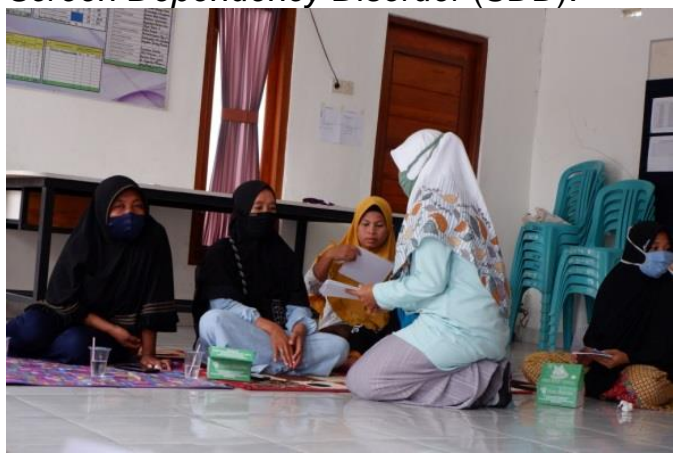

Gambar 3. Pembagian Modul Screen Dependency Disorder (SDD)

d. Tim memaparkan materi Screen Dependency Disorder (SDD) yang telah dirangkum dalam power point menggunakan media LCD. Materi yang dipaparkan yaitu pengertian gadget, pengertian Screen Dependency Disorder (SDD), jenis- jenis Screen Dependency Disorder (SDD), dampak gadget, lama penggunaan gadget, jarak pandang gadget, pencegahan kecanduan gadget.

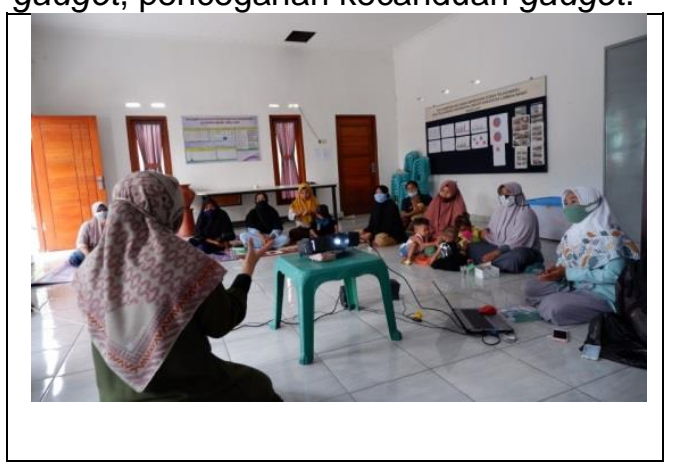

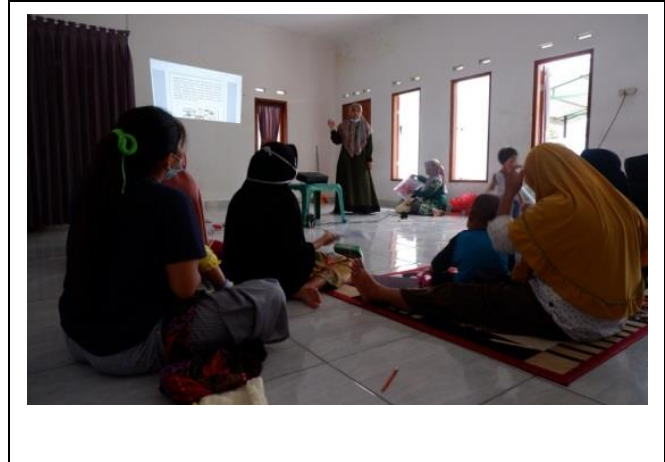

Gambar 4. Pemaparan Teori Dampak dan Pencegahan Screen Dependency Disorder (SDD)

\section{Observasi dan Evaluasi}

Observasi dilakukan terhadap peningkatan pengetahuan pada ibu tentang dampak dan pencegahan Screen Dependency Disorder (SDD) pada lbu yang memiliki balita di Desa Telagawaru Kecamatan Labuapi Kabupaten Lombok Barat. Observasi yang dilakukan yaitu menganalisis pengetahuan responden dengan mengisi pre test materi Screen Dependency Disorder (SDD) dan post test yang dilakukan setelah tim pengabdian memaparkan materi. Hasil Evalusi didapatkan pengetahuan ibu tentang penggunaan gadget $40 \%$ memiliki pengetahuan kurang, setelah dilakukan post test pengetahuan ibu meningkat, didapatkan $80 \%$ ibu meningkat yaitu Baik.

\section{Kontribusi Mitra Terhadap Pelaksanaan}

Mitra dalam kegiatan pengabdian berperan aktif :

1. Perangkat desa aktif dalam memfasilitasi kader yang ditunjuk dalam kegiatan pengabdian dan lokasi tempat pelaksanaan pengabdian

2. Kader, mahasiswa dan tim pengabdian aktif berdiskusi dalam perencanaan kegiatan dan alat dan bahan serta teknik pelaksanaan kegiatan

3. keikutsertaan aktif dan antusian juga terlihat pada responden yang hadir datang tepat waktu dan mengikuti kegiatan hingga selesai, responden juga memperhatikan protokol kesehatan selama jalannya kegiatan pengabdian.

\section{Potret Permasalahan Lain Dalam Kegiatan}

Potret permasalahan lain yang terekam selama kegiatan pengabdian:

1. Adanya pengabaian pada anak selama memainkan gadget dengan terlihat banyaknya anak yang menggunakan gadget lebih dari 1 jam dalam sehari. 
2. Kurangnya upaya orang tua mengasuh anak secara interaktif dan kreatif untuk mengalihkan perhatian anak terhadap kebiasaan penggunaan gadget, hal ini dipengaruhi pola asuh yang diterima oleh anak.

3. Masa Pandemi memperburuk kondisi anak dalam kebiasaannya memainkan gadget, orang tua dengan kesibukannya masingmasing di rumah, agar tidak terganggu oleh anak dalam berkegiatan, didapatkan hampir $100 \%$ orang tua akhirnya mengalihkan perhatian anak yaitu dengan menggunakan gadget.

\section{SIMPULAN DAN SARAN}

Tim Pengabdian Masayarakat sudah memberikan informasi dan edukasi dampak dan pencegahan screen dependency disorder (sdd) selama masa pandemi pada ibu balita di desa telagawaru lombok barat Pada 10 responden. Tim Pengabdian sudah memberikan pre test dan post test dalam kegiatan ini didapatkan pengetahuan ibu tentang penggunaan gadget $40 \%$ memiliki pengetahuan kurang, setelah dilakukan post test pengetahuan ibu meningkat, didapatkan $80 \%$ ibu meningkat yaitu Baik. Peserta dibekali modul screen dependency disorder yang dapat dibawa pulang sebagai bahan edukasi peserta di rumah.

\section{UCAPAN TERIMAKASIH}

Tim penulis mengucapkan terima kasih kepada Kementrian Riset dan Teknologi/Badan Riset dan Inovasi Nasional (Ristek-BRIN) yang telah mendanai kegiatan pengabdian ini sehingga terlaksana dengan baik. Lembaga Penelitian dan Pengabdian Masyarakat Universitas Muhammadiya dan Mitra Pengabdian Masyarakat yang telah mendukung dan memfasilitasi kegiatan pengabdian sehingga berjalan dengan lancar.

\section{DAFTAR RUJUKAN}

Depkes., R. (2016) 'Pedoman pelaksanaan stimulasi, deteksi, dan intervensi tumbuh kembang anak.'

Heath A and Bainbridge N (2007) Baby Massage: Kekuatan Menenangkan dari Sentuhan. Jakarta: Dian Rakyat.

Kementerian Koordinator Bidang Kesejahteraan Rakyat (2013) 'Kerangka Kebijakan Gerakan Nasional Percepatan Perbaikan Gizi dalam Rangka Seribu Hari Pertama Kehidupan (Gerakan 1000 HPK)', p. 71. Kementrian Kesehatan RI (2018) 'Menjaga Kesehatan Ibu \& Anak', Warta Kesmas,
3, p. 48. Available at:

http://www.kesmas.kemkes.go.id/asset s/upload/dir_519d41d8cd98f00/files/W arta-kesmas-edisi-3-2018_1219.pdf.

Luz Yolanda Toro Suarez (2019) 'Statistik Telekomunikasi Inodensia', pp. 1-27.

Priyoto (2014) Teori Sikap dan Prilaku dalam Kesehatan. Yogyakarta: Nuha Medika.

Setianingsih, S. (2018) 'Dampak Penggunaan Gadget Pada Anak Usia Prasekolah Dapat Meningkatan Resiko Gangguan Pemusatan Perhatian Dan Hiperaktivitas', Gaster, 16(2), p. 191. doi: 10.30787/gaster.v16i2.297.

Wulandari, D. and Hermiati, D. (2019) 'Deteksi Dini Gangguan Mental dan Emosional pada Anak yang Mengalami Kecanduan Gadget', Jurnal Keperawatan Silampari, 3(1), pp. 382392. doi: $10.31539 / j k s . v 3 i 1.843$.

Yaumi, Muhammad dan Damopolii, M. (2014) Action Research: Teori, Model, dan Aplikasi. Jakarta: Kencana. 